\title{
Assessment of Low Temperature Refining Process of Castor Seed Oil for Biodiesel Production
}

\author{
Chika Muhammad ${ }^{1}$, Muhammad Mukhtar ${ }^{1}$, Muhammad Sabiu Jibrin ${ }^{2}$, Musa Usman Dabai ${ }^{1}$, \\ Aliyu Sarkin Baki ${ }^{3}$ \\ ${ }^{1}$ Department of Pure and Applied Chemistry, Usmanu Danfodiyo University, Sokoto, Nigeria \\ ${ }^{2}$ Department of Pure and Industrial Chemistry, Bayero University, Kano, Nigeria \\ ${ }^{3}$ Department of Microbiology, Usmanu Danfodiyo University, Sokoto, Nigeria
}

Email address:

mmukhtar02@gmail.com (M. Mukhtar)

\section{To cite this article:}

Chika Muhammad, Muhammad Mukhtar, Muhammad Sabiu Jibrin, Musa Usman Dabai, Aliyu Sarkin Baki. Assessment of Low Temperature Refining Process of Castor Seed Oil for Biodiesel Production. American Journal of Chemical and Biochemical Engineering.

Vol. 3, No. 1, 2019, pp. 1-6. doi: 10.11648/j.ajcbe.20190301.11

Received: September 23, 2018; Accepted: January 2, 2019; Published: January 29, 2019

\begin{abstract}
In recent years research on biodiesel production from non-edible seed oil is receiving more attention to prevent food vs biofuels problems such as starvation in developing countries. Castor seed oil is potential non-edible biodiesel feedstock, but it has high viscosity and high acid value which are among the undesired factors in biodiesel production. The castor seed oil was extracted using soxhlet extraction method, refined using standard analytical methods and its physicochemical properties was determined using ASTM methods. The crude extracts of castor seeds oil which was characterized as high viscous oil, was refined to improve its quality, and physicochemical properties of refined and crude extracts castor seed oil was studies. The crude extracts oil $(41.29 \pm 1.54 \%)$ produce was refined to reduce its high viscosity $\left(233.0 \pm 2.00 \mathrm{~mm}^{2} / \mathrm{s}\right)$ and acid value $(4.488 \pm 0.40$ $\mathrm{mgKOH} / \mathrm{g}$ ). The viscosity and acid value of the oil significant reduced to $159.0 \pm 3.00 \mathrm{~mm}^{2} / \mathrm{s}$ and $2.805 \pm 0.20 \mathrm{mgKOH} / \mathrm{g}$ after the refining process. The others physicochemical properties such as flash point, saponification value, iodine value, moisture contents, specific gravity, refractive index, kinematic viscosity, cloud point, pour point and free fatty acids qualities were improved after refining. The study show that refined castor seed oil were more suitable in biodiesel production than crude castor seed oil.
\end{abstract}

Keywords: Castor Seed Oil, Soxhlet Extraction, Refining, Physicochemical Properties

\section{Introduction}

Castor oil has natural antibacterial and antifungal properties and is high in vitamin E, minerals, proteins and Omega 6 and 9 beneficial fatty acids. Its unusually have high ricinoleic acid ratio, which makes it beneficial to skin and hair. In fact, castor oil has traditionally been used topically for acne and other skin conditions, as well as hair loss, rashes and more [1]. Now, castor oil is massively used in biodiesel and bio-lubricants productions because of its unique physicochemical properties. The general problem of vegetable oils that make it difficult to be used as fuel are their high viscosity which affects their fluidity in engine and high acid value which may cause corrosion in the engine. So, there is need for pretreatments in order to reduce the viscosity and acid value [2].
Castor seed, Ricinus communis L., is a member of the tropical spurge family, Euphorbiaceae, and can nowadays be found naturalized and cultivated in all temperate countries of the world. It belongs to a monotypigenus, Ricinus, and sub tribe, Ricininae. The evolution of castor and its relation to other species are currently being studied.

Castor is amongst the plants with the highest oil yield potential because of its high yield of seeds and the high oil content of its seeds [3]. It may be possible to obtain a maximum of $2000 \mathrm{~kg}_{\text {oil }} \cdot \mathrm{hr}^{-1}{ }^{1}$. Whereas rapeseed produces about $1000 \mathrm{~kg}_{\text {oil }} \cdot \mathrm{hr}^{-1}$ and soybean only produces about 500 $\mathrm{kgoil}^{\circ} \mathrm{ha}^{-1}[4]$. Therefore, castor oil is a promising source to produce biodiesel, decreasing the cultivated land. 


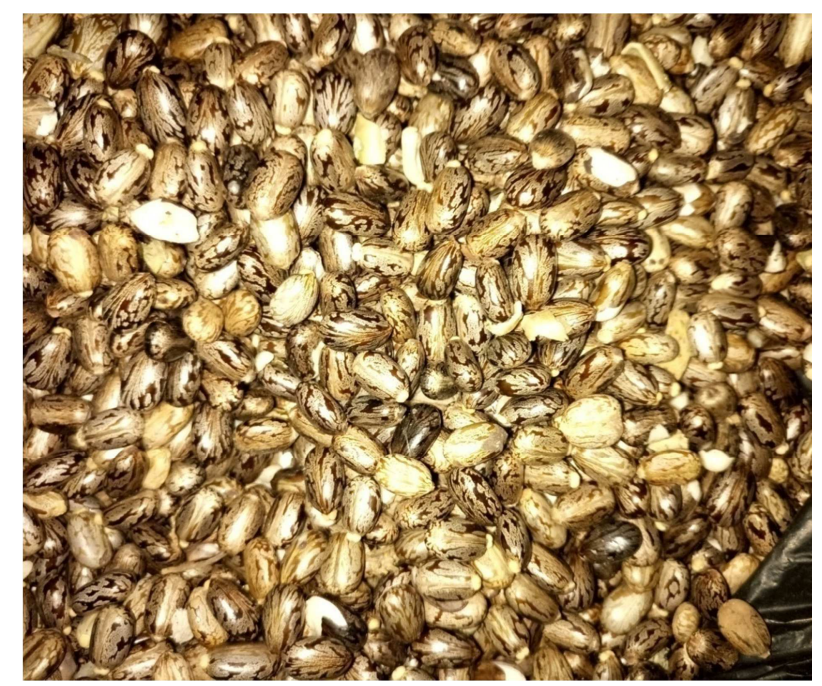

Figure 1. Castor seeds.

About chemical and physical characteristics, castor oil composition is $80-90 \%$ ricinoleic acid, 3-6 \% linoleic acid, $2-4 \%$ oleic acid and 1-5\% saturated fatty acids [1]. Ricinoleic acid is the main fatty acid from castor oil, this fatty acid possesses 18 carbons with three highly reactive functional groups: the carbonyl group in $1^{\text {st }}$ carbon, the double linking or unsaturation in $9^{\text {th }}$ carbon and the hydroxyl group in $12^{\text {th }}$ carbon. This feature causes castor oil properties are different from other vegetable oils [5]. The high content of ricinoleic acid, with a hydroxyl group, is the reason for castor oil has especially high viscosity and density. Castor oil is also characterized by its high stability, high hygroscopicity and its solubility in alcohol, which affects the transesterification reaction [6].

\section{Material and Methods}

\subsection{Preproduction Process}

The Castor seed was procured from Yandodo, Kano State. The seed was sundried to reduce the moisture content and it was then grinded to reduce the particle size in preparation for extraction. The Castor seed was de-shelled. The de-shelled seed which was white in color was oven dried at $90^{\circ} \mathrm{C}$ for 45 minutes. The dried seeds were grounded using motor and pestle and weighed.

\subsection{Oil Extraction Process}

Extraction of castor oil was carried out by soxhlet extraction method. $100 \mathrm{~cm}^{3}$ of $\mathrm{n}$-hexane was placed in round bottom glass flask, $50.0 \mathrm{~g}$ of the sample was placed in thimble and settled in the center of the extractor and Soxhlet apparatus was heated at $108^{\circ} \mathrm{C}$. The solvent boiled and vaporized through the vertical tube into the condenser at the top. The condensate liquid started dropping into the thimble containing the sample and the extracted oil seeped through thimble into the flask via the siphon. After each hour the sample was dried at $70^{\circ} \mathrm{C}$ and weighed until the residue weight became constant. At this stage the amount of extracted oil was determined at the end of each extraction cycle. The oil-solvent mixture was oven heated at $108^{\circ} \mathrm{C}$ for solvent recovery [7]; [8]. The yield of the oil was determined using equation 1 :

$$
\% \text { extracted oil yield }=\frac{\text { weight of oil extracred }(g)}{\text { weight of the sample }(g)} \times 100 \%
$$

\subsection{Pretreatment of Extracted Oil}

\subsubsection{Degumming}

Exactly $100 \mathrm{~cm}^{3}$ of crude castor oil was weighed into 250 $\mathrm{cm}^{3}$ beaker placed on hotplate magnetic stirrer with agitation at $600 \mathrm{rpm}$ and heated to $85^{\circ} \mathrm{C}, 100 \mathrm{~cm}^{3}$ of distilled water was added and allowed under the same condition for 30 minutes. The mixture was transferred into separating funnel and allowed to settle for 15 minutes, the oil which was at upper layer was separated by draining the lower layer. The oil was then taken back into a beaker and reheated to $85^{\circ} \mathrm{C}$ at $600 \mathrm{rpm}$, $60 \mathrm{~cm}^{3}$ of $0.1 \mathrm{M}$ of phosphoric acid was added and allowed for 30 minutes. $80 \mathrm{~cm}^{3}$ of distilled water was added and allowed for another 10 minutes before transferred into $500 \mathrm{~cm}^{3}$ separating funnel and allowed it to settle for 15 minutes. The degummed oil at the upper layer was separated by draining the lower layer. $100 \mathrm{~cm}^{3}$ of distilled water was added into separating funnel containing only degummed oil and was shaken for two minutes and allowed to settle. The water at lower layer was drained by opening the tab on the separating funnel. The washing was repeated for 3 times to ensure purity of the degummed oil [2].

\subsubsection{Neutralization}

The $100 \mathrm{~cm}^{3}$ of degummed castor oil was heated to $85^{\circ} \mathrm{C}$ in $500 \mathrm{~cm}^{3}$ beaker on a hotplate magnetic stirrer with agitation of $600 \mathrm{rev} / \mathrm{min}$. $25 \mathrm{~cm}^{3}$ of $0.5 \mathrm{M}$ of $\mathrm{NaOH}$ was added and allowed for 30 minutes, $100 \mathrm{~cm}^{3}$ of distilled water was added and then transferred into $500 \mathrm{~cm}^{3}$ separating funnel. The neutralized oil at the upper layer was separated from the lower. The neutralized oil was washed three times with $100 \mathrm{~cm}^{3}$ of distilled water. The refined oil was then reheated at $105^{\circ} \mathrm{C}$ for 1 hour to remove moisture [7].

\subsection{Determination of Physicochemical Properties of Crude and Refine Castor Oil}

\subsubsection{Tests for Cloud Point and Pour Points}

The oil sample $\left(5 \mathrm{~cm}^{3}\right)$ was measured in $5 \mathrm{~cm}^{3}$ test tube and placed in a freezer. The sample was taken out of the freezer every 1 minute to check any visible changes and the temperature was measured using digital mex-tech thermometer [9].

Observation for Cloud Point: At a particular temperature, crystals began to form in the sample; reading was taken [10].

Observation for Pour Point: At a certain temperature, gel and crystals were dissolved from sample (it's frozen) and then the temperature reading was taken [10].

\subsubsection{Test for Flash Point}

The flash point was determined according to ASTM D93 method. The sample was placed in the test cup to the prescribed mark in the interior of the cup. The cup was 
mounted on to its position on the tester. Bunsen burner was used to supply heat to the apparatus at rate of $1^{\circ} \mathrm{C}$ per minute with constant stirring. A small test flame was directed into the cup intermittently. The flash point was taken as the temperature when the test flame caused the vapour above the sample to ignite [10].

\subsubsection{Determination of Moisture Content of the Seeds}

The grinded sample (40.0 g) of seeds was weighed, oven dried at $80^{\circ} \mathrm{C}$ for $7 \mathrm{hrs}$, and the weight was recorded every 2 hrs, until a constant weight is obtained. After each $2 \mathrm{hrs}$, samples were removed from the oven, placed in desiccator for 30 minutes, to cool, then removed and re-weighed. The percentage moisture in these seeds was calculated using equation 3 [11]:

$$
\text { Moisture content }=\frac{w_{1}-w_{2}}{w_{2}} \times 100 \%
$$

$\mathrm{W}_{1}=$ Original weight of the sample before drying $\mathrm{W}_{2}=$ Weight of the sample after drying

\subsubsection{Determination of Specific Gravity}

The empty beaker of $50 \mathrm{~cm}^{3}$ capacity was weighed $\left(\mathrm{W}_{0}\right)$, filled with oil, and then reweighed $\left(\mathrm{W}_{1}\right)$. The oil was substituted with water after washing and drying the beaker and weighed $\left(\mathrm{W}_{2}\right)$ [11].

The expression for specific gravity is:

$$
\begin{aligned}
\text { Specific gravity } & =\frac{\text { Mass of substance }}{\text { Mass of equal volume of water }} \\
\text { S. G. } & =\frac{w_{1}-w_{0}}{w_{2}-w_{0}}
\end{aligned}
$$

\subsubsection{Determination of Refractive Index}

Few drops of oil samples were transferred to glass slide of the refractometer. Through the eyepiece of the refractometer, the dark portion viewed was adjusted to be in line with the intersection of the cross, In this case the pointer on the scale pointed to the refractive index and values were recorded [11].

\subsubsection{Determination of Kinematic Viscosity}

The dynamic viscosity was determined using Cannon Viscometer model 2020. The spindle (spindle number 63 and 04 were used) through calibrated spring of viscometer was rotated in $50 \mathrm{~cm}^{3}$ of the sample in $50 \mathrm{~cm}^{3}$ beaker. The viscous drag of the fluid against the spindle was measured by the spring deflection. The spring deflection was measured with a rotator transducer which provides a torque signal. The viscosity in centipoises was displayed on the screen of the viscometer. To obtained kinematic viscosity in centistokes (1centistoke $=1 \mathrm{~mm}^{2} / \mathrm{s}$ ), the dynamic viscosity was divided with density [12].

\subsubsection{Determination of Acid Value}

Equal volume $\left(10 \mathrm{~cm}^{3}\right)$ of each of diethyl ether and ethanol was mixed in a $250 \mathrm{~cm}^{3}$ beaker, then was added to $2.0 \mathrm{~g}$ of oil contained in a $250 \mathrm{~cm}^{3}$ conical flask and few drops of phenolphthalein were added. The mixture was titrated with $0.1 \mathrm{M} \mathrm{KOH}$ to the end point with consistent shaking, a dark pink color was observed and the volume of $0.1 \mathrm{M} \mathrm{KOH}$ was recorded.

Acid value, Free Fatty Acid (FFA) and FFA conversion (\%) were calculated equation 5 [11]:

$$
\begin{aligned}
& \text { Acid value }\left(\frac{\mathrm{mgKOH}}{\text { g sample }}\right)= \\
& \frac{\text { volume } \mathrm{KOH}\left(\mathrm{cm}^{3}\right) \times \mathrm{N} \mathrm{KOH}\left(\mathrm{mmol} / \mathrm{cm}^{3}\right) \times 56.1(\mathrm{mg} / \mathrm{mmol})}{\text { sample weight }(\mathrm{g})}
\end{aligned}
$$

$$
\begin{gathered}
\text { Free Fatty Acid }\left(\frac{\mathrm{mgKOH}}{\text { g sample }}\right)=0.5 \times \text { Acid value } \\
\text { FFA conversion }(\%)=\frac{A_{i}-A_{t}}{A_{t}} \times 100
\end{gathered}
$$

Where $A_{i}=$ the initial acid value; $A_{t}=$ the acid value at a certain reaction time.

\subsubsection{Determination of Saponification Value}

The oil sample $(2.0 \mathrm{~g})$ was weighed into a conical flask and $25 \mathrm{~cm}^{3}$ of $0.1 \mathrm{~N}$ ethanolic potassium hydroxide $(\mathrm{KOH})$ was added. The mixture was constantly stirred and allowed to boil gently for 15 minutes. A reflux condenser was placed on the flask containing the mixture. Few drops of phenolphthalein indicator were added to the warm solution and titrated with $0.5 \mathrm{M} \mathrm{HCl}$ to the end point until pink color of the indicator disappeared. The same procedure was used for other samples and blank. Saponification value was calculated [11]; [13]:

$$
\text { Saponification value }\left(\frac{m g K O H}{g \text { sample }}\right)=56.1 \times \frac{N\left(V_{0}-V_{I}\right)}{W}
$$

$\mathrm{V}_{0}=$ volume of the solution used for blank test

$\mathrm{V}_{\mathrm{I}}=$ volume of the solution of the sample used for determination

$\mathrm{N}=$ Actual normality of the $\mathrm{HCl}$ used

$\mathrm{W}=$ Mass of the sample $(\mathrm{g})$

\subsubsection{Determination of Iodine Value}

Sample of $2.0 \mathrm{~g}$ of oil was weighed into a conical flask and $25 \mathrm{~cm}^{3}$ of carbon tetra chloride $\left(\mathrm{CCl}_{4}\right)$ was added to dissolve the oil. Then $25 \mathrm{~cm}^{3}$ of Dam's reagent was added to the mixture using a safety pipette in fume chamber. Stopper was inserted and the content of the flask was vigorously swirled. The flask was placed in the dark for 2.5 hours. Then, $20 \mathrm{~cm}^{3}$ of $10 \%$ aqueous potassium iodide (KI) and $125 \mathrm{~cm}^{3}$ of water were added using a measuring cylinder. The solution was titrated with $0.1 \mathrm{M}$ sodium thiosulphate $\left(\mathrm{Na}_{2} \mathrm{~S}_{2} \mathrm{O}_{3}\right)$ solutions until the yellow color almost disappeared. Few drops of $1 \%$ starch solution indicator was added and titration continued by adding sodium thiosulphate drop wise until blue coloration disappeared after vigorous shaking. The same procedure was used for blank test and other samples. The iodine value (I. V) was determined by using equation 9 [11];[13].

$$
\text { Iodine value }=\frac{126.9 \times M \times\left(V_{0}-V_{1}\right)}{W}
$$

$\mathrm{M}=$ Concentration of sodium thiosulphate used $\mathrm{V}_{0}=$ Volume of sodium thiosulphate used for blank $\mathrm{V}_{1}=$ Volume of sodium thiosulphate used for determination $\mathrm{W}=$ Mass of the sample $(\mathrm{g})$ 


\section{Results}

The results obtained might vary depending on the method and solvent used for oil extraction, nature and type of sample, environmental factors, method of transesterification etc [11]. The results obtained from these analyses are interpreted as follow:

Table 1. Physicochemical properties of crude and refined castor oil.

\begin{tabular}{llll}
\hline Properties & Unit & Crude castor oil & Refined castor oil \\
\hline Extracted oil yield & $\%$ & $41.29 \pm 1.54$ & $28.09 \pm 0.50$ \\
Moisture content & $\%$ & $2.11 \pm 0.01$ & - \\
Specific gravity & - & $0.9555 \pm 0.01$ & $0.9245 \pm 0.00$ \\
Refractive index & $-\mathrm{C}$ & $1.470 \pm 0.00$ & $1.443 \pm 0.00$ \\
Cloud point & ${ }^{\circ}$ & $3.17 \pm 0.31$ & $4.00 \pm 1.20$ \\
Kinematic viscosity $@ 40^{\circ} \mathrm{C}$ & $\mathrm{mm}^{2} / \mathrm{s}$ & $233.0 \pm 2.00$ & $159.0 \pm 3.00$ \\
Pour point & ${ }^{\circ} \mathrm{C}$ & $-24.0 \pm 2.00$ & $-13.1 \pm 2.00$ \\
Saponification value & $\mathrm{mg}_{\mathrm{KOH}} / \mathrm{g}_{\text {sample }}$ & $182.525 \pm 1.19$ & $169.910 \pm 0.20$ \\
Iodine value & $\mathrm{gI}_{2} / 100 \mathrm{~g}$ & $81.533 \pm 1.35$ & $78.216 \pm 1.80$ \\
Acid value & $\mathrm{mg}_{\mathrm{KOH}} / \mathrm{g}_{\text {sample }}$ & $4.488 \pm 0.40$ & $2.805 \pm 0.20$ \\
Free fatty acid & $\mathrm{mg}_{\mathrm{KOH}} / \mathrm{g}_{\text {sample }}$ & $2.244 \pm 0.20$ & $1.403 \pm 0.10$ \\
Flash point & ${ }^{\circ} \mathrm{C}$ & $225.0 \pm 1.00$ & $190 \pm 1.00$ \\
\hline
\end{tabular}

Values are Arithmetic Mean \pm Standard Deviation of three replicate determinations

\section{Discussion}

\subsection{Refining of Crude Castor Oil}

Refining is a process used to improve the quality of vegetable oil that will gives it characteristic to be use directly as fuel or to undergo upgrade process i.e. transesterification before been use as fuel [7]. There are three steps in refining process i.e. degumming, neutralization and bleaching. The degumming: the purpose of degumming is two folds; On the one hand, it is necessary to remove almost completely phosphatides or gums from the oil in order to produce fully refined oil, and, on the other hand, gums may be valuable by-products [2], neutralization: which is employ to reduce free fatty acid and soap formation and bleaching: to remove colour, odour, impurities and residual soap [7]. In this experiment, it was determined that after every degumming of $100 \mathrm{~g}$ of crude castor oil, $32 \mathrm{~g}$ of gum were removed which was corroborate by saadia, [2] who obtained $30 \mathrm{~g}$ of gum after degumming 100 $\mathrm{g}$ of soya beans oil using $34 \mathrm{~g}$ of phosphoric acid in $58 \mathrm{~cm}^{3}$ of water.

\subsection{Percentage Yield of Oil and Biodiesel}

Castor oil obtained from castor beans contain about $38-60 \%$ of oil which can be used in production of paints, varnishes, lubricants, grease, hydraulic fluids, soaps, pharmaceuticals, cosmetics and so on [7]. The percentage yield of oil extracted from castor seeds oil in this experiment was $41.29 \pm 1.54 \%$ and similar result $(43.18 \%)$ for castor seeds was obtained by Gregory et al., [14], which is high than the value (37\%) for castor seeds reported by Saribiyik et al., [15] and lower than (48\%) that obtained by Nakarmi and Joshi, [7]. The differences may be due to plant growing environment and method of extraction employed. After refining process, the yield reduced by $13.21 \%$ to $28.09 \pm 0.50 \%$. Reductions may be due to removal of hydralable phospholipids, non hydralable phospholipids, metal salts and impurities during degumming and saponifying some free fatty acids and washing them away during neutralization [7].

\subsection{Acid Value}

Acid value (AV) is a common parameter in the specification of fats and oils. It's defined as the weight of $\mathrm{KOH}$ in mg needed to neutralize the organic acids present in $1 \mathrm{~g}$ of fat/ oil and it is measure of the free fatty acids (FFA) presents in the fats or oil. The high acid value implies that the oil has high susceptibility to decomposition [16]. Excess or higher acid and free fatty acid values of oil greater than $5 \%$ is not suitable for base catalyzed transesterification reaction [17]. The acid value of crude castor oil obtained is $4.488 \pm 0.40 \mathrm{mgKOH} / \mathrm{g}$ which is lower than $15.57 \mathrm{mgKOH} / \mathrm{g}$ obtained by Omohu and Omale [16] and high than the maximum value specified by ASTM of $2 \mathrm{mgKOH} / \mathrm{g}$. After neutralization during refining of the crude castor oil, the acid value drop to $2.805 \pm 0.20 \mathrm{mgKOH} / \mathrm{g}$. Nakarmi and Joshi [7] performed similar refining process on the castor oil, where their acid value of the crude castor oil drop from 2.629 to $1.566 \mathrm{mgKOH} / \mathrm{g}$.

\subsection{Saponification Value}

This is the measure of the total free and combined acid in the oil expressed as the number of milligrams of potassium hydroxide required for the complete saponification on $1 \mathrm{~g}$ of the oil [16]. Saponification value is related to the average molecular weight of the sample. The molecular weight is inversely proportional to the saponification value. Saponification values increased with the yield of methyl ester [18]. The saponification of crude castor oil was decreases from $182.525 \pm 1.19$ to $169.910 \pm 0.20 \mathrm{mgKOH} / \mathrm{g}$ after refining. A comparative result was obtained by Nakarmi and Joshi, [7]; where after their refining of castor oil, the saponification value decreases from 79.159 to $76.258 \mathrm{mgKOH} / \mathrm{g}$. Decreases in the saponification value may be due to the facts that certain fatty acids had been neutralized during refining process. Higher saponification value would lead to the formation of more soap during transesterification with basic catalyst, which would 
hinder the biodiesel formation and affect the quality of biodiesel produce [19]. Hence, refined castor with lower saponification value is more preferable for biodiesel production.

\subsection{Iodine Value}

Iodine value, also called Iodine number, in analytical chemistry, measure of the degree of unsaturation of oil/ fat ; the amount of iodine, in grams, that is taken up by 100 grams of the oil/ fat. Saturated oils/ fats take up no iodine; therefore their iodine value is zero; but unsaturated oils/ fats take up iodine [11]. The more iodine is attached, the higher is the iodine value, and the more reactive, less stable, softer, and more susceptible to oxidation and rancidification is the oil $/ \mathrm{fat}^{7}$. Drying oils used in the paint and varnish industry have relatively high iodine values (about 190). Semidrying oils, such as soybean oil, have intermediate iodine values (about 130). Nondrying oils, such as olive oil, used for soap making and in food products, have relatively low iodine values (about 80) [16].

The iodine value of crude and refined castor oil as presented in Table 3.1 are $81.533 \pm 1.35$ and $78.216 \pm 1.80 \mathrm{gI}_{2} / 100 \mathrm{~g}$ which could be categorized as nondrying oil and can be used in soap making. The low iodine values of both crude and refined castor oils indicate their lower degree of unsaturated compound. The refined castor oil has lower iodine value this may be due to hydrolysis that might took place during refining process. The iodine value of crude castor oil is similar with that $\left(80.5 \mathrm{gI}_{2} / 100 \mathrm{~g}\right)$ obtained by Sanchez et al., [20] and lower than $\left(84.19 \mathrm{gI}_{2} / 100 \mathrm{~g}\right)$ and $\left(93.5 \mathrm{gI}_{2} / 100 \mathrm{~g}\right)$ obtained by Enchinar et al., [18] and Omohu and Omale [7].

\subsection{Kinematic Viscosity}

Kinematic viscosity is the most important property of oil because it affects the fluidity, lubricity and atomization of the fuel [21]. Fuels with low viscosity may not provide sufficient lubrication resulting in wear and high viscosity causes poor combustion and increases exhaust emission [22]. The kinematic viscosity of the crude castor oil as presented in Table Table 3.1 is $233 \pm 2.00 \mathrm{~mm}^{2} / \mathrm{s}$ at $40^{\circ} \mathrm{C}$, similar result of $224 \mathrm{~mm}^{2} / \mathrm{s}$ at $40^{\circ} \mathrm{C}$ was obtained by Rengasamy et al., [22] and high results of $258.01 \mathrm{~mm}^{2} / \mathrm{s}$ at $40^{\circ} \mathrm{C}$ was observed by Encinar et al., [23]. After refining, the viscosity dropped to $159.0 \pm 3.00 \mathrm{~mm}^{2} / \mathrm{s}$ at $40^{\circ} \mathrm{C}$. Reduction in the viscosity may be related to the removal heavy materials i.e. hydralable phospholipids, non hydralable phospholipids, metal salts etc. and impurities during refining process [7].

\subsection{Specific Gravity}

The specific gravity is a key fuel property, which affects the mass of fuel injected into the combustion chamber. This property directly affects the engine performance characteristic because the fuel injection pump meter works on by volume not by mass [22]. The specific gravity of crude castor oil was found to be $0.9555 \pm 0.01$ (Table 3.1) and significantly decreases to $0.9245 \pm 0.00$ after refining. Comparable result 0.961 of crude castor oil was obtained by
Encinar et al., [23].

\subsection{Flash Point}

The flash point is the minimum temperature at which fuel gives momentary flash on ignition under specified test conditions. It is an important parameter for storage, handling and safety of the fuel. The flash point of crude castor oil was about $225.0 \pm 1.00^{\circ} \mathrm{C}$ which is lower than $286^{\circ} \mathrm{C}$ that observed by Rengasamy et al., [22] and almost similar with $229^{\circ} \mathrm{C} \mathrm{ICSC}$ (International Chemical Safety Cards) 1452 standard. After refining, the flash point decreases to $190 \pm 1.00^{\circ} \mathrm{C}$ which indicate increased in volatility of the oil. This indicates that both crude and refined castor oil are safe in handling and storage.

\subsection{Cloud Point and Pour Point}

The cloud point is the temperature at which dissolved solids are no longer completely soluble, precipitating as a second phase giving the fluid a cloudy appearance (Rengasamy et al., [22]. While, the pour point is carried out to determines the freezing point of the sample. The cloud and pour point of crude castor oil obtained are $3.17 \pm 0.31$ and $-24.0 \pm 2.00^{\circ} \mathrm{C}$. Rengasamy et al., [22] observed the cloud point of crude castor oil as $14^{\circ} \mathrm{C}$, While the Forero, [24] observed the pour point as $-23^{\circ} \mathrm{C}$. The cloud point and pour point changed after refining process to $4.00 \pm 1.20$ and $-13.1 \pm 2.00^{\circ} \mathrm{C}$.

\subsection{Refractive Index}

This is the measure of the extent to which radiation is refracted on passing through the interface between two media. It indicates the clarity of the oil. The refractive index analysis show significant difference between the value $1.470 \pm 0.00$ of the crude and $1.443 \pm 0.00$ of the refined castor oil, this may be attributed to the fact that some impurities and other components were removed during refining Akpan et al., [11]. Also, Akpan et al., [11] observed differences between the value obtained for crude castor oil 1.4686 and that of the refined oil 1.467 .

\section{Conclusion}

The low temperature refining pretreatments was achieved at $85^{\circ} \mathrm{C}$ which improved the physicochemical properties and efficiency of castor oil that can be used in biodiesel production and produces by products i.e. hydralable phospholipids e.g. phosphotidal choline, phosphotidal ethanalamine etc and non hydralable phospholipids which may be used as raw materials for some industries.

\section{References}

[1] Scholz, V. and da Silva, J. N. Prospects and Risks of the Use of Castor Oil as a Fuel. Biomass and Bioenergy, 32: 95-100. (2008).

[2] Saadia, M. A. Degumming of Soybean Oil. Fats and Oil Department, National Research Centre, Dokki, Cairo, Egypt. 43 Fasc. 5. (1992). 
[3] Ismail, S., Ahmad, A. S., Anr, R. and Hamdan, S, Biodiesel Production from Castor Oil by Using Calcium Oxide Derived from Mud Clam Shell. Journal of Renewable Energy, (2016): 5274917, http://dx.doi.org/10.1155/2016/5274917, 12/03/ 2017 at $02: 45 \mathrm{pm}$.

[4] Balat, M. and Balat, H Progress in Biodiesel Processing. Applied Energy, 87: 1815-1835. . (2010).

[5] Conceição, M. M., Candeia, R. A., Silva, F. C., Bezerra, A. F. Fernandes, J. V. J. and Souza, A. G. Thermoanalytical Characterization of Castor Oil Biodiesel. Renewable and Sustainable Energy Reviews, 11: 964-975. (2007).

[6] Ogunniyi, D. S. Castor oil: A vital industrial raw material. Bioresource Technology, 97:1086-1091. (2006).

[7] Nakarmi, A. and Joshi, S. A study on Castor Oil and its Conversion into Biodiesel by Transesterification Method. Nepal Journal of Science and Technology, 15(1): 45-52. (2014).

[8] Edison M., John K., Philiswa M. and Mohamed B. Optimization of Process Parameters for Castor Oil Production. Proceedings of the World Congress on Engineering, 3. WCE, July 4 - 6, 2012, London, UK, ISBN: 978-988-19252-2-0, ISSN: 2078-0958 (Print); ISSN: 2078-0966 (online). (2012).

[9] ASTM, American Standard for Testing of Materials, Characteristics of Jatropha curcas Oil. Journal of American Oil and Chemist Society, 85: 2671-2675. (2008).

[10] Fuduka, H., Kando, A. and Noda, H., Biodiesel Fuel Production by Transesterification of Oils. Journal of Bioscience and Bioengineering, (92): 405-415. (2001).

[11] Akpan, U. G., Jimoh, A. and Mohammed, A. D. Extraction, Characterization and Modification of Castor Seed Oil. Leonardo Journal of Sciences, 8: 43-52. (2006).

[12] Cannon manual, Manual viscometer; Operating Instruement. Cannon Instrument Company, 2139 High Tech Road, State College, PA, Manual No. CM/98-350-B0806, 4- 10. (2017).

[13] Kyari, M. Z. Extraction and Characterization of Seed Oils. Intanational Agrophysiscs, 22: 139-142. (2008).

[14] Gregory, C. R., Smith, R. N. and Simpson, L. Castor Bean Production: The CARDI Experience, Castor Growers Workshop, Jamaica Castor Industry Association (JAMPRO Building), Kingston 10, pp. 10. (2017).
[15] Saribiyik, O. Y., Ŏzcanli, M., Serin, H., Serin, S. and Aydin, K. Biodiesel Production from Ricinus Communis Oil and its Blends with Soybean Biodiesel. StronjniŠki Vestnik- Journal of Mechanical Engineering, 56(12): 811-816. (2010).

[16] Omahu, O. J. and Omale, A. C. Physicochemical Properties and Fatty Acid Composition of castor Bean Ricinus Communis L. Seed Oil. American Journal of Applied and Industrial Chemistry, 3(1): 1-4. (2017). doi: 10.11648/j.ajaic.20170301.11.

[17] Remesh, M., Biodiesel Production: Review. Bioresource Technology, 70: 1-15. (2004).

[18] Encinar, J. M., González, J. F. and Rodríguez, A. R. Biodiesel from Used Frying Oil. Variables Affecting the Yields and Characteristics of the Biodiesel. Industrial and Engineering Chemistry Research, 44: 5491-5499. (2005).

[19] Lam, M. K., Lee K. T. and Mohamed, A. R. Homogeneous, Heterogeneous and Enzymatic Catalysis for Transesterification of High Free Fatty Acid Oil (waste cooking oil) to Biodiesel: A Review. Biotechnology Advances, 28: 500-518. (2010).

[20] Sánchez, N., Encinar, J. M., Martinez, G. and González, J. F. Biodiesel Production from Castor Oil under Subcritical Method Conditions. International Journal of Environmental Science and Development. 6(1): 562, (2015). doi: 10.7763/IJESD.2015.

[21] Sattanathan, R. Production of Biodiesel from Castor Oil with its Performance and Emission Test. International Journal of Science and Research (IJSR), ISSN (online): 2319- 7064. Index Copernicus value (2013): 6.14|Impact Factor (2013): 4.438. (2013).

[22] Rengasamy, M., Mohanraj, S., Vardhan, S. H., Balaji, R. and Pugalenthi V. Transesterification of Castor Oil Using Nano-sized Iron Catalyst for the Production of Biodiesel. Journal of Chemical and Pharmaceutical Science, JCHPS Special Issue 2, (2014). ISSN: 0974- 2115.

[23] Encinar, J. M., Gonzalez, J. F., Martinez, G., Sanchez, N. and Gonzalez, C. G. Synthesis and Characterization of Biodiesel Obtained from Castor Oil Transesterification. International Conference on Renewable Energy and Power Quality (ICREPQ 11), 1(9): 1078- 1083. (2010).

[24] Forero, C. L. B. Biodiesel from Castor Oil: a Promising Fuel for Cold Weather. Renewable Energies and Power Quality Journal, 1(3): 59-62. (2005). 